\title{
The Optimum Dose of Thyroxine Hormone Supplementation in Broodstock Mud Crab (Scylla Serrata) to Accelerate Ovarian Maturation
}

Heppi Iromo ${ }^{1 *}$, Zairin Junior $\mathbf{M}^{1}$, Agus Suprayudi $\mathbf{M}^{\mathbf{1}}$ and Wasmen Manalu²

${ }^{1}$ Department of Aquaculture, Faculty of Fisheries and Marine Science, Bogor Agricultural University, Bogor, Indonesia

${ }^{2}$ Department of Anatomy, Physiology, and Pharmacology, Faculty of Veterinary Medicine, Bogor Agricultural University, Bogor, Indonesia

\begin{abstract}
This experiment was designed to study the optimum dose of thyroxine supplementation in accelerating ovarian maturity in broodstock mud crab (Scylla serrata). The production of mud crab is very low since the production system relies on the natural harvesting that has not applied aquaculture technology optimally. The low productivity in natural culture is thought to be related to the low magnitude of biological process and metabolism that support optimum reproduction system such as the slow and low rate of vitellogenesis. The ovarian maturity is started by the synthesis and the release of vitellogenin into the hemolymph and then transported to the ovum to be used as a precursor of egg yolks synthesis. The thyroxine hormone is found in the follicle and assists the process of yolk absorption. This study used 4 levels of thyroxine supplementation i.e., $0 \mu \mathrm{g} / \mathrm{g} \mathrm{BW}$ (control), $0.05 \mu \mathrm{g} / \mathrm{g} \mathrm{BW,} 0.10 \mu \mathrm{g} / \mathrm{g} \mathrm{BW}$ and 0.15 $\mu \mathrm{g} / \mathrm{g}$ BW. In general, the supplementation of thyroxine significantly improved the rate of ovarian maturity $(P<0.05)$. Supplementation of thyroxine at the dose of $0.10 \mu \mathrm{g} / \mathrm{g} \mathrm{BW}$ gave the highest rate of ovarian maturity. Supplementation of thyroxine increased yolk absorption during ovarian maturity. It was also found that thyroxine supplementation increased concentrations of protein and RNA/DNA during ovarian maturity.
\end{abstract}

Keywords: Mud crab; Maturity ovarian; Thyroxine supplementation

\section{Introduction}

The mud crab (Scylla serrata) is one of the commercially important crabs and the only species of the genus Scylla in the Indian Ocean. It has both ecological and economic importance to the marine environment and to the coastal fishing villages. However, the production and availability of crab seeds is the main problem in culture of mud crabs. To solve the problem, there is a need to develop a technique to propagate the crab by improving the reproduction of the crab and the survival of the larvae.

Mud crab reproduction requires considerable time to produce larvae starting from vitellogenesis processes that occur in the body until the embryonic development occurred outside the body. Many factors influencing the process are internal factors and external factors. Internal factors are physiological and genetic conditions of the crab such as the synthesis of hormones that regulate the function of the body. External factors are such as feed and the environment.

In crustacean, female reproduction is controlled by a variety of hormonal and neuronal factors [1]. These hormones include the neuropeptide hormones, such as the gonad stimulating hormone, and the vitellogenin inhibiting hormone which have an agonist-antagonist effect, respectively, on vitellogenesis. Thyroid hormone is required by all cells in the body to stimulate enzyme synthesis required for cellular metabolism, especially for anabolic processes. Thyroxine hormone in the circulation of the broodstock can be transferred into the oocyte, the egg, and then into the ovary (yolk sac) before ovulation [2]. Thyroid hormones indirectly facilitate the absorption of the vitellogenin from the circulation into the developing oocyte to form egg yolk. Thyroxine hormone can easily enter the target cells through the cell membrane.

The research on thyroxine hormone in mub crab is limited. Similarly, the physiological level of thyroxine hormone is not widely recorded, both in the broodstock and the larvae. The present experiment was designed to study the effect of thyroxine hormone supplementation on the rate of vitellogenesis and ovarian maturation in female S. Serrata.

\section{Materials and Methods}

\section{Animal}

The females mud crab (Scylla serrata) of various maturation stages were obtained from traditional ponds and mangroves in Tarakan Island, North Borneo, Indonesia. The identification of Scylla serrata was conducted according to the description of Kennan [3]. The weights of female mud crabs used ranged from 350 to $450 \mathrm{~g}$. The female $S$. serrata were classified according to the stage of ovarian maturity [4] i.e., vitellogenesis stage 1 (immature), vitellogenesis stage 2 (premature), and vitellogenesis stage 3 (mature). The experimental mud crabs were reared in fiberglass tank with volume of 1000 liters with a sandy base $(10 \mathrm{~cm}$ high) at the bottom that was provided with the shelter on the top. A berried female was transferred into a 80-liters holding tank equipped with a flow-through water system.

\section{Experimental design}

The thyroxine hormone preparation used in the experiment was Levothyroxine sodium tablets (Thyrax, NV Organon Oss, The Netherlands). Each tablet contains $100 \mathrm{mg}$ of thyroxine. The thyroxine hormone supplementation was conducted once at vitellogenesis stage 2 (premature). The levels of thyroxine hormone supplementations were $0 \mu \mathrm{g} / \mathrm{g} \mathrm{BW}$ (control); $0.05 \mu \mathrm{g} / \mathrm{g} \mathrm{BW} ; 0.1 \mu \mathrm{g} / \mathrm{g} \mathrm{BW}$, and $0.15 \mu \mathrm{g} / \mathrm{g} \mathrm{BW}$. Each treatment was repeated three (3) times. The supplementation

*Corresponding author: Heppi Iromo, Department of Aquaculture, Faculty of Fisheries and Marine Science, Bogor Agricultural University, Bogor, Indonesia, Tel 6285213396636; E-mail: sholat_dhuha@yahoo.co.id

Received July 25, 2014; Accepted January 19, 2015; Published February 15 2015

Citation: Iromo H, Zairin Junior M, Agus Suprayudi M, Manalu W (2015) The Optimum Dose of Thyroxine Hormone Supplementation in Broodstock Mud Crab (Scylla Serrata) to Accelerate Ovarian Maturation. J Aquac Res Development 6 : 317. doi:10.4172/2155-9546.1000317

Copyright: $\odot 2015$ Iromo $\mathrm{H}$, et al. This is an open-access article distributed under the terms of the Creative Commons Attribution License, which permits unrestricted use, distribution, and reproduction in any medium, provided the original author and source are credited. 
of thyroxine hormone was conducted by injection with $1 \mathrm{~mL}$ spuid between the road and swimming legs. Concentrations of thyroxine hormone in the hemolymph were measured before thyroxine thyroxine supplementation during vitellogenesis stage 2 (premature) and 3 (mature) by using the ELISA method (DRG International Inc., USA).

\section{Chemical analysis}

Cholesterol, phospholipid, neutral lipid, protein, DNA and RNA concentrations in the hemolymph were measured at the vitellogenesis stage 2 (premature) and 3 (mature). Cholesterol concentrations in the ovaries were determined by Lieberman-Burchards method. Phospholipids (PL) and the neutral lipid (NL) concentrations in the ovary were measured by Seppak. Protein concentration and RNA/DNA in the hemolymph was measured by Nanadrop 2000 Spectrophotometer thermo scientific with Absorbance 1 at $280 \mathrm{~nm}$.

\section{Statistical analysis}

Thyroxine concentrations in the hemolymph and the concentrations of cholesterol, neutral lipid, phospholipid and protein in the ovary were analyzed by the analysis of variance.

\section{Results}

Thyroxine hormone concentrations in the female S. serrata during immature, premature and mature ovarian maturity increased during ovarian maturation (Table 1). The data showed that before supplementation (during immature ovarian maturity), thyroxine hormone concentrations in the hemolymph were similar in all groups of experimental mud crabs. Supplementation of thyroxine hormone in female S. Serrata increased the concentrations of thyroxine hormone in the hemolymph during ovarian maturity. Supplementation of thyroxine with a dose of $0.05 \mu \mathrm{g} / \mathrm{g}$ BW did not significantly increase hemolymph thyroxine concentration as compared to control $(\mathrm{P}>0.05)$. However, supplementation of thyroxine at the dosages of 0.10 and 0.15 $\mu \mathrm{g} / \mathrm{g}$ BW significantly increased hemolymph thyroxine concentrations $(\mathrm{P}<0.05)$. There was no significant difference in hemolymph thyroxine concentrations between 0.10 and $0.15 \mu \mathrm{g} / \mathrm{g}$ BW dosages of thyroxine supplementations.

\begin{tabular}{|c|c|c|c|}
\hline $\begin{array}{c}\text { Dosages of thyroxine } \\
\text { supplementation }(\boldsymbol{\mu} \mathbf{g} / \mathbf{g} \\
\text { BW) }\end{array}$ & Immature & Premature & Mature \\
\hline 0 & $5.00 \pm 0.28^{\mathrm{a}}$ & $5.50 \pm 0.28^{\mathrm{a}}$ & $7.10 \pm 0.42^{\mathrm{a}}$ \\
\hline 0.05 & $5.30 \pm 0.42^{\mathrm{a}}$ & $7.00 \pm 0.42^{\mathrm{a}}$ & $8.70 \pm 1.13^{\mathrm{a}}$ \\
\hline 0.10 & $5.20 \pm 0.28^{\mathrm{a}}$ & $9.00 \pm 1.41^{\mathrm{b}}$ & $13.00 \pm 1.41^{\mathrm{b}}$ \\
\hline 0.15 & $5.50 \pm 0.85^{\mathrm{a}}$ & $9.80 \pm 0.14^{\mathrm{b}}$ & $10.20 \pm 0.71^{\mathrm{b}}$ \\
\hline
\end{tabular}

Different superscripts in the same column indicate a significant different $(P<0.05)$

Table 1: Thyroxine hormone concentrations $(\mathrm{ng} / \mathrm{mL})$ in the hemolymph at different follicle development stages of female mud crabs (Scylla serrata) supplemented with thyroxine. supplementation (vitellogenesis stage 1 or immature) and after

Supplementation of thyroxine hormone increased protein synthesis in the body of the mud scrubs as indicated by the increased protein, DNA and RNA concentrations in the hemolymph (Table 2). Supplementation of thyroxine hormone increased protein, DNA, and RNA concentrations in the hemolymph during ovarian maturation process $(\mathrm{P}<0.05)$. There was an indication that protein, $\mathrm{DNA}$, and RNA concentrations in the hemolymph increased with the advanced ovarian maturity from premature to mature stages. The highest increase in protein, RNA, and DNA concentrations in the hemolymph was found in the dose of $0.1 \mu \mathrm{g} / \mathrm{g}$ BW.

There was a tendency that concentration of cholesterol and phospholipid in the ovaries increased with the advanced of ovarian maturity from premature to mature (Table 3 ). However, neutral lipid had different patterns i.e., decreased with the advance of ovarian maturity. In general, there was no significant effect of thyroxine supplementation on cholesterol, neutral lipid, and phospholipid concentrations $(\mathrm{P}>0.05)$.

Gonadal somatic index (GSI) of the experimental mud crabs did not different among dosages of thyroxine supplementations in premature and mature ovarian developments $(\mathrm{P}>0.05)$. In mature of female mud crabs, the average values of GSI increased dramatically (Table 4). In mature female mud crabs, supplementation of thyroxine hormones tended to increase GSI.

Duration (days) of ovarian maturity development starts from vitellogenesis stage II to berried. In general, the results of the experiment showed that thyroxine supplementation accelerated the ovarian maturity either from premature to mature or from mature to berried (Table 5). Supplementation of thyroxine hormone increased the rates of ovarian maturities in the experimental crabs $(\mathrm{P}<0.05)$. Supplementation of thyroxine hormone with a dose of $0.10 \mu \mathrm{g} / \mathrm{g} \mathrm{BW}$ gave the fastest ovarian maturity (24 days). Increased dose of thyroxine supplementation to $0.15 \mu \mathrm{g} / \mathrm{g}$ BW, decreased the ovarian maturity to 25 days. Supplementation of thyroxine hormone with the lowest dose of $0.05 \mu \mathrm{g} / \mathrm{g} \mathrm{BW}$ gave the slowest rate of ovarian maturity to 31 days. Unsupplemented mud crabs (control) had the longest ovarian maturity (55 days). This data indicated that thyroxine hormone supplementation accelerated ovarian maturity until berried. The survival rate of the experimental crabs were similar either in control or in crabs supplemented with thyroxine $(\mathrm{P}>0.05)$ (Table 5).

Female fecundity was also observed to determine the effect of thyroxine supplementation (Table 6). Fecundity is the number of eggs that can be produced by crab females. The results showed that the highest fecundity values found in crabs supplemented with thyroxine hormone at a dose of $0.15 \mu \mathrm{g} / \mathrm{g} \mathrm{BW}\left(1.86 \times 10^{6}\right)$ followed by the dose of $0.1 \mu \mathrm{g} / \mathrm{g}$ BW, dose $0.05 \mu \mathrm{g} / \mathrm{g} \mathrm{BW}$, and control dose $0 \mu \mathrm{g} / \mathrm{g}$ BW. However, there was no significant effect of thyroxine supplementation on fecundity $(\mathrm{P}>0.05)$.

The body size of the female crabs affects the fecundity, ovulation rate, and fertilization rate. The results showed that the highest fecundity

\begin{tabular}{|c|c|c|c|c|c|c|}
\hline \multirow{2}{*}{$\begin{array}{c}\text { Dosages of thyroxine } \\
\text { supplementation } \\
(\mu \mathrm{g} / \mathrm{g} \mathrm{BW})\end{array}$} & \multicolumn{2}{|c|}{$\begin{array}{c}\text { Protein } \\
(\mathrm{mg} / \mathrm{mL})\end{array}$} & \multicolumn{2}{|c|}{ 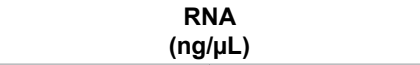 } & \multicolumn{2}{|c|}{ 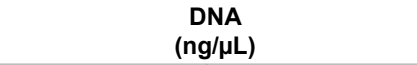 } \\
\hline & Premature & Mature & Premature & Mature & Premature & Mature \\
\hline 0 & $42.46 \pm 2.06^{a}$ & $50.38 \pm 3.88^{a}$ & $21.61 \pm 0.74^{a}$ & $29.80 \pm 4.74^{a}$ & $5.97 \pm 0.39^{a}$ & $11.24 \pm 5.09^{a}$ \\
\hline 0.05 & $57.42 \pm 2.63^{b}$ & $67.91 \pm 3.43^{b}$ & $26.79 \pm 5.2^{\mathrm{a}}$ & $36.57 \pm 1.40^{\mathrm{b}}$ & $14.39 \pm 1.19^{b}$ & $16.51 \pm 4.29^{b}$ \\
\hline 0.10 & $63.71 \pm 3.19^{c}$ & $77.94 \pm 5.76^{c}$ & $31.19 \pm 1.48^{b}$ & $38.06 \pm 5.39^{b}$ & $17.83 \pm 2.94^{c}$ & $19.83 \pm 1.71^{c}$ \\
\hline 0.15 & $62.97 \pm 4.24^{c}$ & $76.35 \pm 8.59^{c}$ & $22.57 \pm 9.29^{a}$ & $36.11 \pm 1.29^{b}$ & $11.83 \pm 3.45^{b}$ & $17.71 \pm 1.52^{b}$ \\
\hline
\end{tabular}

Different superscripts in the same column indicate a significant different $(P<0.05)$

Table 2: Protein and RNA/DNA concentrations in the hemolymph at different follicle development stages of female mud crabs (Scylla serrata) supplemented with thyroxine. 
Citation: Iromo H, Zairin Junior M, Agus Suprayudi M, Manalu W (2015) The Optimum Dose of Thyroxine Hormone Supplementation in Broodstock Mud Crab (Scylla Serrata) to Accelerate Ovarian Maturation. J Aquac Res Development 6: 317. doi:10.4172/2155-9546.1000317

Page 3 of 4

\begin{tabular}{|c|c|c|c|c|c|c|}
\hline \multirow{2}{*}{$\begin{array}{c}\text { Dose } \\
(\mu \mathrm{g} / \mathrm{g} B W)\end{array}$} & \multicolumn{2}{|c|}{ Cholesterol } & \multicolumn{2}{|c|}{ Neutral lipid } & \multicolumn{2}{|c|}{ Phospholipid } \\
\hline & Premature & Mature & Premature & Mature & Premature & Mature \\
\hline 0.00 & $0.34 \pm 0.04^{a}$ & $0.33 \pm 0.01^{a}$ & $37.84 \pm 4.12^{\mathrm{a}}$ & $38,01 \pm 2.11^{a}$ & $62.17 \pm 4.12^{a}$ & $61.99 \pm 2.11^{a}$ \\
\hline 0.05 & $0.32 \pm 0.04^{a}$ & $0.32 \pm 0.01^{\mathrm{a}}$ & $37.11 \pm 1.64^{a}$ & $38,04 \pm 2.39^{a}$ & $62.89 \pm 1.64^{a}$ & $61.96 \pm 2.39^{a}$ \\
\hline 0.10 & $0.35 \pm 0.03^{b}$ & $0.32 \pm 0.01^{\mathrm{a}}$ & $34.15 \pm 2.32^{\mathrm{a}}$ & $37.94 \pm 2.61^{\mathrm{a}}$ & $65.85 \pm 2.32^{a}$ & $62.07 \pm 2.61^{a}$ \\
\hline 0.15 & $0.37 \pm 0.03^{b c}$ & $0.35 \pm 0.01^{a}$ & $34.64 \pm 2.96^{a}$ & $37,64 \pm 1.57^{a}$ & $65.36 \pm 2.96^{a}$ & $62.36 \pm 1.57^{a}$ \\
\hline
\end{tabular}

Different superscripts in the same column indicate a significant different $(\mathrm{P}<0.05)$

Table 3: Cholesterol, neutral lipid, and phospholipid concentrations (\%) in the ovaries at different follicle development stages of female mud crabs (Scylla serrata) supplemented with thyroxine.

\begin{tabular}{|c|c|c|}
\hline $\begin{array}{c}\text { Dosages of thyroxine supplementation } \\
(\boldsymbol{\mu g} / \mathbf{g} \text { BW) }\end{array}$ & \multicolumn{2}{|c|}{ Gonadal Somatic Index (GSI) } \\
\hline 0.00 & Premature & $3.30 \pm 0.81^{\mathrm{a}}$ \\
\hline 0.05 & $0.98 \pm 0.07^{\mathrm{a}}$ & $3.48 \pm 0.69^{\mathrm{a}}$ \\
\hline 0.10 & $0.97 \pm 0.15^{\mathrm{a}}$ & $4.19 \pm 0.09^{\mathrm{a}}$ \\
\hline 0.15 & $1.00 \pm 0.06^{\mathrm{a}}$ & $4.16 \pm 0.52^{\mathrm{a}}$ \\
\hline
\end{tabular}

Same superscript in the same column indicate a nonsignificant different $(P>0.05)$

Table 4: Gonadal somatic index (GSI) at different follicle development stages of female mud crabs (Scylla serrata) supplemented with thyroxine.

\begin{tabular}{|c|c|c|c|c|c|}
\hline $\begin{array}{c}\text { Dosages of thyroxine } \\
\text { supplementation }(\boldsymbol{\mu g} / \mathbf{g ~ B W})\end{array}$ & $\begin{array}{c}\text { Ovarian maturity } \\
(\%)\end{array}$ & $\begin{array}{c}\text { Time from premature to } \\
\text { mature (days) }\end{array}$ & $\begin{array}{c}\text { Time from mature to } \\
\text { berried (days) }\end{array}$ & $\begin{array}{c}\text { Time from embryo to } \\
\text { hatching (days) }\end{array}$ & $\begin{array}{c}\text { Survival rate } \\
(\%)\end{array}$ \\
\hline 0 & $55.6(n=12)^{\mathrm{a}}$ & $23 \pm 3.83^{\mathrm{a}}$ & $32 \pm 3.27^{\mathrm{a}}$ & $14 \pm 2.31^{\mathrm{a}}$ \\
\hline 0.05 & $77.8(\mathrm{n}=12)^{\mathrm{b}}$ & $16 \pm 2.00^{\mathrm{b}}$ & $15 \pm 2.00^{\mathrm{b}}$ & $14 \pm 2.31^{\mathrm{a}}$ \\
\hline 0.1 & $77.8(\mathrm{n}=12)^{\mathrm{b}}$ & $13 \pm 2.00^{\mathrm{c}}$ & $11 \pm 2.00^{\mathrm{c}}$ & $12 \pm 0.00^{\mathrm{a}}$ \\
\hline 0.15 & $77.8(\mathrm{n}=12)^{\mathrm{b}}$ & $12 \pm 0.00^{\mathrm{c}}$ & $13 \pm 1.15^{\mathrm{b}}$ & $100^{\mathrm{a}}$ \\
\hline
\end{tabular}

Different superscripts in the same column indicate a significant different $(P<0.05)$

Tabel 5: Ovarian maturity, development of ovary to berried, and survival rates of stages of female mud crabs (Scylla serrata) supplemented with thyroxine.

\begin{tabular}{|c|c|c|}
\hline $\begin{array}{c}\text { Dosages of thyroxine } \\
\text { supplementation }(\boldsymbol{\mu g} / \mathbf{g} \text { BW) }\end{array}$ & Fecundity & Body weight $(\mathbf{g})$ \\
\hline 0.00 & $1.71 \times 10^{6 \mathrm{a}} \pm 1.64 \times 10^{5}$ & $380 \pm 27.84^{\mathrm{a}}$ \\
\hline 0.05 & $1.72 \times 10^{6 \mathrm{a}} \pm 1.61 \times 10^{5}$ & $375 \pm 35.00^{\mathrm{a}}$ \\
\hline 0.10 & $1.79 \times 10^{6 \mathrm{a}} \pm 2.66 \times 10^{5}$ & $400 \pm 25.00^{\mathrm{a}}$ \\
\hline 0.15 & $1.86 \times 10^{6 \mathrm{a}} \pm 1.30 \times 10^{5}$ & $401 \pm 20.00^{\mathrm{a}}$ \\
\hline
\end{tabular}

Different superscripts in the same column indicate a significant different $(P<0.05)$

Table 6: Fecundity of female mud crabs (Scylla serrata) supplemented with thyroxine.

was observed in female crabs supplemented with thyroxine at the doses of $0.15 \mu \mathrm{g} / \mathrm{g}$ BW and then followed by dosages $0.1 \mu \mathrm{g} / \mathrm{g} \mathrm{BW}, 0.5 \mu \mathrm{g} / \mathrm{g}$ BW, and control $0.00 \mu \mathrm{g} / \mathrm{g}$ BW. The body weights of the experimental crabs were not different among groups of thyroxine supplementations.

\section{Discussion}

The results of this experiment clearly indicated that supplementation of thyroxine hormone in the mature female Scylla serrata significantly increased the concentrations of the hormone in the hemolimph that is available for being absorbed by other organs, such as ovary during ovarian maturation. Thyroxine hormone in the circulation of the broodstock can be transferred into the oocyte, egg, and then into the ovary (yolk sac) before ovulation [2].

The increased thyroxine hormone concentrations in the hemolymph could increase thyroxine availability in the active cells that will facilitate metabolism in the cells such as protein synthesis (as enzymes or products) that was indicated by the increased concentrations of DNA and RNA in the hemolymph. During gonadal development, protein is needed for growth and development of the ovaries that could be mobilized from the body protein reserves [5]. The results of this study indicate that there are similarities between the patterns of increase in thyroxine hormone concentrations in the hemolymph and the degree of ovarian maturity. It clearly indicates the close relationship between the thyroxine hormone concentrations in the body with the improvement of ovarian maturity in the broodstock.

The increase in protein synthesis and metabolic rate affect reproductive performance [6]. Conversely, the decrease in protein synthesis during gonadal development will affect the success of reproduction such as ovarian maturation and embryonic growth and development. The result of this experiment strongly showed that supplementation of thyroxine hormone increased the rate of protein synthesis in the body. The increased protein synthesis and DNA and RNA concentrations in the hemolymph during thyroxine supplementation had a similar pattern with ovarian maturity.

Thyroid hormones (T3 and T4) control energy homeostasis and metabolism as well as protein and lipid synthesis. The influence of the thyroxine hormones in protein synthesis is through the transcription of the DNA into RNA that is finally translated into a protein synthesis. The interactions of thyroid hormone and receptor at the nucleus increased the activity of polymerase enzyme and RNA synthesis [7]. The increase in transcription of DNA into RNA and protein synthesis implies that thyroxine supplementation facilitates the synthesis of protein component of vitellogenin and their further absorption for deposition in the developing ovum.

The concentration of cholesterol, phospholipids, and neutral lipid were increase with the increased development of ovarian maturity. This indicates that the optimum availability of thyroxine hormone in the cells will optimize the absorption of lipid during vitellogenesis. There is always an increase lipid concentration during ovarian development from immature to mature stages and the level is maintained at mature ovaries and decreased after spawning [8]. Low lipid concentration in the hepatopancreas in mature ovaries could imply the movement of 
Citation: Iromo H, Zairin Junior M, Agus Suprayudi M, Manalu W (2015) The Optimum Dose of Thyroxine Hormone Supplementation in Broodstock Mud Crab (Scylla Serrata) to Accelerate Ovarian Maturation. J Aquac Res Development 6: 317. doi:10.4172/2155-9546.1000317

Page 4 of 4

the lipid component from hepatopancreas to the ovaries during the maturation process.

In Crustacea, phospholipids are used as components of cell membranes. The higher concentration of phospholipids in female $S$. serrata after thyroxine supplementation indicates that the hormone facilitates the synthesis of lipid to phospholipids in the hepatopancreas. Gonadal Somatic Index (GSI) of female mud crabs increased and reached the maximum level during the spawning time (Table 4).

The reproduction of female Crustacean is controlled by the endocrine system. The dominant cellular activity occurring during the development of the ovary is the synthesis of yolk component that is called vitellogenesis. During this process, vitellogenin (Vg), an egg yolk precursor protein, is accumulated in the developing oocytes. This process leads to the changes in the gonads. Vitellogenesis process is started from the signal released by the granulosa layer of the follicle oocytes into the blood, and stimulates the liver to synthesize vitellogenin. Once synthesized, vitellogenin is released into the blood and then selectively is absorbed by the oocyte. Vitellogenesis is an important step in the maturation of the ovary. Vitellogenin can be synthesized in the ovarium and other nonovarian organs such as hepatopancreas [9].

Thyroid hormone has long been known to have an important role in early development. Thyroid hormone, either T3 or T4, enters the target cells by the plasma proteins. This hormone does not directly assist the process of yolk absorption. In the follicles, thyroxine binds to thyroglobulin. It is known that T4 is a hormone that is important in stimulating the growth and development of gonad. The results of this experiment confirm that thyroxine supplementation increased metabolic activity as indicated by the increased protein synthesis that is parallel with ovarian maturity.

Ovarian maturity is occurred when there is a deposition of vitellogenin in the ovum that is started by the synthesis of vitelogenin in the hepatopancreas. Vitellogenin is secreted by the hepatopancreas into the hemolymph and taken to the ovum to be synthesized into egg yolk [10]. Through the hemolymph, vitellogenin is selectively absorbed by a layer of follicle oocytes [11-13]. This process is known as vitellogenesis, while the next step is the final maturation process in which there is a movement to the edge of the egg nucleus, or germinal vesicle fusion and ovulation is marked by the rupture of the follicle and the release of the egg layer into the cavity of the ovaries [11-13]. Egg yolks will be a source of nutrients for embryonic development [13]. The raw material of vitellogenin is vitellin, which is synthesized by extraovarium tissue and it is released into the hemolymph in response to vitellogenin stimulating ovarian hormone (VSOH). However, the fecundity of the experimental crabs is not affected by the thyroxine supplementation. The weight of broodstock is the dominant factor affecting fecundity, spawning frequency, and degree of fertilization.

\section{Conclusion}

Thyroxine hormone supplementation at a dose of $0.1 \mu \mathrm{g} / \mathrm{g}$ BW in broodstock mud crab (Scylla serrata) accelerated ovarian maturation and hatching rate of the ovum through the improvement of vitellogenesis process.

\section{References}

1. Subramoniam $T$ (2000) Crustacean ecdysteroids in reproduction and embryogenesis. Comp Biochem Physiol 125: 135-156.

2. Ayson FG, Lam TJ (1993) Thyroxine injection of female rabbitfish (Siganus guttatus) broodstock: changes in thyroid hormone levels in plasma, eggs, and yolk-sac larvae, and its effect on larval growth and survival. Aquaculture 109 83-93.

3. Keenan CP, Davie PJF, Mann DL (1998) A revision of the genus Scylla De Haan, 1833 (Crustacea: Decapoda: Brachyura: Portunidae). Raffles Bull Zool 46: $217-245$

4. John S, Sivadas P (1978) Morfological changes in development of the ovary in the eyestalk ablated estuarine crab, Scylla serrata (Forskal). Mahasagar 11 $57-62$

5. Altiner A (2006) Study of serum growth hormone, 3,5,5'-triiodothyronine thyroxine, total protein and free fatty acids levels during parturition and early lactation in ewes. Bul Vet Inst Pulawy 50: 85-87.

6. Clowes EJ, Aherne FX, Foxcroft GR, Baracos VE (2003) Selective protein loss in lactating sows is associated with reduced litter growth and ovarian function. J Anim Sci 81: 753-764.

7. Djojosoebagio S (1990) Fisiologi Endocrinology Gland: Departement of Education and Culture. Bogor Agricultural University, Indonesian.

8. Teshima SI, Kanazawa A, Sasada H (1983) Nutritional value of dietary cholesterol and other sterols to larval prawn, Penaeus japonicus Bate. Aquaculture 31: 159-167.

9. Treerattrakool S, Panyim S, Chan SM, Withyachumnarnkul B, Udomkit A (2008) Molecular characterization of gonad-inhibiting hormone of Penaeus monodon and elucidation of its inhibitory role in vitellogenin expression by RNA interference. FEBS Journal 275: 970-980.

10. Yano T (1992) Assays of hemolytic complement activity.

11. Zairin M (2003) Endocrinology and role for the future of Indonesian fisheries.

12. Yaron Z, Sivan B (2006) Reproduction.

13. Silversand C, Johan Hyllner S, Haux C (1993) Isolation, immunochemica detection, and observations of the instability of vitellogenin from four teleosts. J Exp Zoo 267: 587-597. 